\title{
Bioactivity evaluation against Artemia salina Leach of medicinal plants used in Brazilian Northeastern folk medicine
}

\author{
Arcanjo, DDR. ${ }^{a *}$, Albuquerque, ACM. ${ }^{a}$, Melo-Neto, B. ${ }^{b}$, Santana, LCLR. ${ }^{b}$, \\ Medeiros, $M G F^{b}$ and Citó, AMGL. ${ }^{c}$ \\ aDepartment of Biophysics and Physiology, Federal University of Piauí - UFPI, \\ Campus Universitário Ministro Petrônio Portella, Ininga, CEP 64049-550, Teresina, PI, Brazil \\ ${ }^{b}$ Department of Biochemistry and Pharmacology, Federal University of Piauí - UFPI, Teresina, PI, Brazil \\ 'Department of Chemistry, Federal University of Piauí - UFPI, Teresina, PI, Brazil \\ *e-mail: daniel.arcanjo@ufpi.edu.br
}

Received July 12, 2011 - Accepted September 5, 2011 - Distributed August 31, 2012

\begin{abstract}
The brine shrimp (Artemia salina Leach) lethality bioassay offers an advantage in standardization and quality control of botanical products. This test is well correlated with antitumor activity (cytotoxicity) and can be used to monitor the activity of bioactive natural products. This paper reports the bioactivity of ethanol extracts from seven medicinal plants from the Northeast of Brazil (Acmella uliginosa, Ageratum conyzoides, Eugenia uniflora, Plectranthus neochilus, Moringa oleifera, Justicia pectoralis and Equisetum sp.) against Artemia salina. Biological activity was evaluated for extracts at $1,10,100$, and $1000 \mu \mathrm{g} / \mathrm{mL}$ in triplicate, and the mean lethal concentration values $\left(\mathrm{LC}_{50}\right)$ were obtained by probit analysis. The species Acmella uliginosa showed the highest bioactivity, and its flower extract was more active than its leaf extract.
\end{abstract}

Keywords: medicinal plants, bioassay, lethality, Artemia salina.

\section{Avaliação da bioatividade frente à Artemia salina Leach de plantas medicinais utilizadas na medicina popular na Região Nordeste do Brasil}

\begin{abstract}
Resumo
O bioensaio em Artemia salina Leach oferece uma vantagem na padronização e no controle de qualidade de produtos botânicos. Esse teste é bem correlacionado com a atividade antitumoral (citotoxicidade) e pode ser usado para monitorar a atividade de produtos naturais bioativos. Este trabalho relata a bioatividade de extratos etanólicos de sete plantas medicinais (Acmella uliginosa, Ageratum conyzoides, Eugenia uniflora, Plectranthus neochilus, Moringa oleifera, Justicia pectoralis e Equisetum sp.) contra Artemia salina. A bioatividade foi avaliada em triplicata paraextratos nas concentrações de 1, 10, 100 e $1000 \mu \mathrm{g} / \mathrm{mL}$, e os valores das concentrações letais para metade dos animais $\left(\mathrm{CL}_{50}\right)$ foram obtidos por meio da análise de probitos. A espécie Acmella uliginosa apresentou a maior bioatividade frente à Artemia salina e o extrato etanólico de suas flores apresentou maior atividade do que o das folhas.
\end{abstract}

Palavras-chave: plantas medicinais, bioensaio, letalidade, Artemia salina. 


\section{Introduction}

Since the beginning, man has used natural products to heal their diseases. Over time, indigenous people, healers and religious leaders held the knowledge of medicinal plants and they often symbolize the only therapeutic option for many communities and ethnic groups (Elisabetsky and Souza, 2003; López, 2006). Comments about the popular use and efficacy of medicinal plants contribute significantly to the dissemination of therapeutic properties of plants, commonly used by their medical effects, although chemical constituents sometimes are not known (López, 2006).

Specimens of Artemia salina Leach (brine shrimp), a marine microcrustacean, are used as target organisms to detect bioactive compounds in plant extracts and the toxicity test against these animals has shown a good correlation with antitumor activity (McLaughlin and Rogers, 1988). The significant correlation between the brine shrimp assay and in vitro growth inhibition of human solid tumor cell lines demonstrated by the National Cancer Institute (NCI, USA) is significant because it shows the value of this bioassay as a pre-screening tool for antitumor drug research (Anderson et al., 1991). Thereby, this bioassay is an advantage when evaluating botanical product bioactivity, leading to a development of new drugs.

The main reason why this salt-water anostracan crustacean is used widely for toxicity testing of plant extracts is due to the commercial availability of dormant eggs (cysts), which are harvested in huge amounts in salt lakes and pans. The larvae hatched from the cysts are used worldwide in aquaculture and in aquariology as live food for juvenile fish. Dormant brine shrimp eggs remain viable for many years and are therefore a suitable biological source for rapid, simple and inexpensive bioassays (Mayorga et al., 2010).

The first work in the use of A. salina bioassay was published in 1956, and thereafter, numerous articles have been reported in the literature on environmental studies, using natural products and toxins, including plant extracts (Nunes et al., 2009; Almeida-Cortez et al., 2004; Citó et al., 2003; Cavalcante et al., 2000; Lieberman, 1999). Many Natural Product laboratories have used this assay in their routines of isolation, purification and structural elucidation as an initial biologic screening technique, in order to select and monitor the phytochemical study of plant extracts in the search for bioactive substances (Almeida-Cortez et al., 2004; Siqueira et al., 1998).

In the present study, we evaluated some crude extracts from medicinal plants popularly used in Brazilian folk medicine against Artemia salina.

\section{Material and Methods}

\subsection{Botanical source and preparation of extracts}

Seven medicinal plants were randomly chosen, as follows: Acmella uliginosa (Sw.) Cass (Asteraceae); Ageratum conyzoides L. (Asteraceae); Eugenia uniflora L. (Myrtaceae); Plectranthus neochilus Schltr. (Lamiaceae);
Moringa oleifera L. (Moringaceae); Justicia pectoralis L. (Acanthaceae) and Equisetum sp. L. (Equisetaceae). All plant specimens were cultivated and kindly provided by Medicinal and Aromatic Plants Center (NUPLAM) from the Federal University of Piauí, Brazil. The botanical material from all plants were dried at room temperature and then powdered. The powder was exhaustively extracted with ethanol $99.8 \%$ by maceration at room temperature. The ethanol extract solvent was evaporated to dryness under reduced pressure and lyophilized.

\subsection{Establishment of bioactivity in brine shrimp bioassay}

The brine shrimp bioassay was performed according to the methodology proposed by Meyer et al. (1982), with some modifications (Nunes et al., 2009). From $20 \mathrm{mg}$ of each extract, 1, 10, 100 and $1000 \mu \mathrm{g} / \mathrm{mL}$ solutions were prepared in triplicate. Then, 10 specimens with 48 hours of hatching in sea water and distilled water $(1: 1)$ were placed in each tube and three negative control tubes (saline solution and DMSO 1\%). Appropriate volumes of the saline solution in tubes were added until $5 \mathrm{~mL}$ of saline solution containing 10 nauplii each to obtain the final sample concentrations. After 24 hours, the number of deaths was counted and results were tabulated and submitted to probit analysis in SPSS ${ }^{\circledR} 19.0$ software (IBM ${ }^{\circledR}$ Corp., NY, USA), obtaining the value of $\mathrm{LC}_{50}$ with a $95 \%$ confidence interval.

\section{Results}

In our studies, 4 out of 7 species showed biologic activity in this bioassay. $\mathrm{LC}_{50}$ values for evaluated extracts are shown in Table 1. The species Acmella uliginosa induced the highest biological activity among the species studied, followed by extracts of Plectranthus neochilus, Ageratum conyzoides and Eugenia uniflora. Additionally, flower extract was more active than leaf extract from Acmella uliginosa. Remaining species showed $\mathrm{LC}_{50}$ above $1000 \mu \mathrm{g} / \mathrm{mL}$. Therefore, they showed no bioactivity.

\section{Discussion}

The brine shrimp bioassay is a simple, rapid and low cost test, and it can be performed in a laboratory of natural product chemistry, due to no requirement for aseptic techniques (Lieberman, 1999). These labs are not adequately equipped to perform routine bioassays using animals or isolated organs and tissues. Therefore, the need to perform tests with simple and expeditious procedures led to the search for new tests (Cavalcante et al., 2000).

The relevance of this work is based on the importance of brine shrimp bioassay to determine biological activity of medicinal plants commonly used by different people and ethnic groups, and thereby guide determination of possible biological activities, aiming to evaluate their potential therapeutic indications and safety profile. Substances submitted to this bioassay, which lead to death half specimens at a lethal concentration of up to $1000 \mathrm{mg} / \mathrm{mL}$ 
Table 1. $\mathrm{LC}_{50}$ values for some medicinal plant extracts against Artemia salina.

\begin{tabular}{|c|c|c|c|c|}
\hline \multirow{2}{*}{ Medicinal plant } & \multirow{2}{*}{ Part extracted } & \multirow{2}{*}{$\begin{array}{c}\mathrm{LC}_{50} \\
(\mu \mathrm{g} / \mathrm{mL})\end{array}$} & \multicolumn{2}{|c|}{ Confidence interval $(95 \%)$} \\
\hline & & & Lower & Upper \\
\hline Acmella uliginosa (Sw.) Cass & $\mathrm{Fl}$ & 18.76 & 11.8 & 32.00 \\
\hline Acmella uliginosa (Sw.) Cass & Le & 126.27 & 81.56 & 202.75 \\
\hline Plectranthus neochilus Schltr. & AP & 210.31 & 147.67 & 369.42 \\
\hline Ageratum conyzoides L. & AP & 245.72 & 168.34 & 400.62 \\
\hline Eugenia uniflora L. & AP & 288.45 & 194.24 & 433.67 \\
\hline Moringa oleifera L. & AP & $>1000.0$ & ND & ND \\
\hline Justicia pectoralis L. & $\mathrm{AP}$ & $>1000.0$ & ND & ND \\
\hline Equisetum sp. L. & $\mathrm{AP}$ & $>1000.0$ & ND & ND \\
\hline
\end{tabular}

Le (leaves); Fl (flowers); AP (aerial parts); ND (not determined).

$\left(\mathrm{LC}_{50}\right)$, are considered actives, and thus a good potential for antitumor activity. They were subsequently tested in these trials, obtaining a good correlation (McLaughlin and Rogers, 1988).

Several studies have tried to correlate the toxicity against Artemia salina using activities such as antifungal, virucidal and antimicrobial (MacBae et al., 1988), parasiticide (Sahpaz et al., 1994), trypanocidal (Zani et al., 1995), among others, including the correlation study between growth and chemical defense related to a resource of biocompounds from some medicinal plants (AlmeidaCortez et al., 2004). In several studies, McLaughlin and colleagues have systematically used this bioassay in preliminary evaluation of extracts of plants known as antitumor (Colman-Saizarbitoria et al., 1995; McLaughlin and Rogers, 1988; Meyer et al., 1982). Therefore, several species of medicinal plants were studied using this bioassay.

Acmella uliginosa is used in folk medicine in two ways: its leaves are used in the treatment of respiratory diseases due to expectorant and tonic action (Longuefosse and Nossin, 1996; Agra et al., 2007), and its flowers are used to relieve mouth ulcers, toothache, caries, sore throat and stomach ache (Nakatani and Nagashima, 1992; Albuquerque et al., 2007; Ong et al., 2010), due to local anesthetic action related to a class of substances called N-isobutylamides (Nakatani and Nagashima, 1992; Ramsewak et al., 1999). Therefore, we decided to separately evaluate both extracts, never related before, and the difference between $\mathrm{LC}_{50}$ values seems to be related to the medicinal use of each ones.

Plectranthus neochilus is an aromatic herb used in folk medicine for treating hepatic insufficiency and dyspepsia and is commonly called "boldo" or "boldo-gambá" in Brazil. Its fresh leaves have a distinct odour and are taken as infusion or aqueous extract for healing purposes (Lorenzi and Matos, 2002). Lukhoba et al (2006) published an extensive review of ethnobotanical uses for the genus Plectranthus in digestive disorders such as stomach pain, nausea, vomiting, diarrhoea, mouth and throat infections, and they are used as purgatives, carminatives and as antihelmintics and other diseases. However, the studied species was not mentioned. Duarte and Lopes (2007) reported a morphological study of Plectranthus neochilus aiming at the correct differentiation between various species of the genus Plectranthus and other genus commonly called "boldo", all used in folk medicine to treat diseases of the digestive tract. The brine shrimp lethality induced by Plectranthus neochilus ethanol extract provides an indication of antitumor activity for this species, still not reported in literature, and seems to be associated with antitumor and larvicide activities for other species of the genus Plectranthus (Gurgel et al., 2009; Tadesse et al., 2009).

Ageratum conyzoides exerts a range of biological activity, such as antimicrobial activity, wound healing for burns, to treat colic, diarrhea, flatulence, and acute rheumatism, vasoconstrictor, analgesic and anti-inflammatory (Barbosa et al., 1994; Durodola, 1977; Ladeira et al., 1987). The antitumor activity was reported in a study by Ravishankar et al. (1994), and afterwards by Momesso et al. (2009), and this effect is probably attributed to the flavonoids in the plant. It also contains pyrrolizidine alkaloids, present in flowering branches, which showed high liver toxicity (Castro et al., 2006). This is the first report for activity of Ageratum conyzoides ethanol extract against Artemia salina, and it is consistent with the antitumor activity previously reported.

Coelho de Souza et al. (2004) reported several uses for Eugenia uniflora in folk medicine in Brazil and their pharmacological properties, mainly as an antihypertensive, adstringent and antimicrobial drug. Its aerial parts present many pharmacological properties, including anti-giardial (Brandelli et al., 2009), antimicrobial (Holetz et al., 2002; Coelho de Souza et al., 2004), and toxicity in fish hepatopancreas (Fiuza et al., 2009). So far, no reports have been found of antitumor activity or lethality in brine shrimp bioassay. Therefore, this study is important for reporting these properties for Eugenia uniflora.

Where as $1000 \mu \mathrm{g} / \mathrm{mL}$ as the maximum concentration for a substance is considered active, these results provide an excellent indicator of antitumor activity for these species, due to the good correlation between brine shrimp bioassay and this activity. Therefore, it represents an increase in assessing new drugs and developing new medicines.

Acknowledgements - We would like to thank CNPq and FAPEPI for supporting this research and Prof. Dr. Francisco Rodrigues 
Leal (Medicinal and Aromatic Plants Center (NUPLAM) from the Federal University of Piauí, Brazil) for cultivating and kindly providing all studied plant specimens.

\section{References}

AGRA, MF., BARACHO, GS., NURIT, K., BASÍLIO, IJLD. and COELHO, VPM., 2007. Medicinal and poisonous diversity of the flora of "Cariri Paraibano", Brazil. Journal of Ethnopharmacology, vol. 111, no. 2, p. 383-395. PMid:17236731.

ALBUQUERQUE, UP., MEDEIROS, PM., ALMEIDA, ALS., MONTEIRO, JM., LINS NETO, EMF., MELO, JG. and SANTOS, JP., 2007. Medicinal plants of the caatinga (semi-arid) vegetation of NE Brazil: A quantitative approach. Journal of Ethnopharmacology, vol. 114, no. 3, p. 325-354. PMid:17900836. http://dx.doi. org/10.1016/j.jep.2007.08.017

ALMEIDA-CORTEZ, JS., SHIPLEY, B. and ARNASON, JT., 2004. Growth and chemical defense in relation to resource availability: tradeoffs or common responses to environmental stress? Brazilian Journal of Biology, vol. 64, no. 2, p. 187-194. PMid:15462290.

ANDERSON, JE., GOETZ, CM., McLAUGHLIN, JL. and SUFFNESS, M., 1991. A blind comparison of simple benchtop bioassay and human tumour cell cytotoxicities as antitumor prescreens. Phytochem Analysis, vol. 2, p. 107-111. http://dx.doi. org/10.1002/pca.2800020303

BARBOSA, AD., FERREIRA, RCV. and VALENTE, PHM., 1994. Atividade antimicrobiana de extratos fluidos de plantas medicinais brasileiras. Lecta, vol. 12, p. 153-163.

BRANDELLI, CLC., GIORDANI, RB., DE CARLI, GA. and TASCA, T., 2009. Indigenous traditional medicine: in vitro anti-giardial activity of plants used in the treatment of diarrhea. Parasitology Research, vol. 104, p. 1345-1349. PMid:19153765. http://dx.doi.org/10.1007/s00436-009-1330-3

CASTRO, HG., FERREIRA, FA., SILVA, DJH. and RIBEIROJUNIOR, JI., 2006. Análise do crescimento de acessos de mentrasto (Ageratum conyzoides L.) em dois ambientes. Revista Ciência Agronômica, vol. 37, p. 44-49.

CAVALCANTE, MF., OLIVEIRA, MCC., VELANDIA, JR. and ECHEVARRIA, A., 2000. Síntese de 1.3, 5-triazinas substituídas e avaliação da toxicidade frente a Artemia salina Leach. Química Nova, vol. 23, no. 1, p. 20-22.

CITÓ, AMGL., SOUZA, AA., LOPES, JAD., CHAVES, MH., COSTA, FB., SOUSA, SAA. and AMARAL, MPM., 2003. Resina de Protium heptaphyllum March (Burceraceae): Composição química do óleo essencial e avaliação citotóxica frente a Artemia salina Leach. Anais da Associação Brasileira de Química, vol. 52, no. 2 , p. 74-76.

COELHO DE SOUZA, G., HAAS, APS., POSER, GL., SCHAPOVAL, EES. and ELISABETSKY, E., 2004. Ethnopharmacological studies of antimicrobial remedies in the south of Brazil. Journal of Ethnopharmacology, vol. 90, p. 135-143. PMid:14698521. http://dx.doi.org/10.1016/j.jep.2003.09.039

COLMAN-SAIZARBITORIA, T., GU, ZM., ZHAO, G., ZENG, L., KOZLOWSKI, JF. and McLAUGHLIN, JL., 1995. Venezenin: A New Bioactive Annonaceous Acetogen in from the Bark of Xylopia aromatic. Journal of Natural Products, vol. 58, no. 4, p. 532-539. PMid:7623031. http://dx.doi.org/10.1021/np50118a008

DUARTE, MR. and LOPES, JF., 2007. Stem and leaf anatomy of Plectranthus neochilus Schltr., Lamiaceae. Revista Brasileira de Farmacognosia, vol. 17, no. 4, p. 549-556. http://dx.doi. org/10.1590/S0102-695X2007000400013

DURODOLA, JI., 1977. Antibacterial property of crude extracts from herbal wound healing remedy - Ageratum conyzoides. Planta Medica, vol. 32, p. 388-390. PMid:594219. http://dx.doi. org/10.1055/s-0028-1097620

ELISABETSKY, E. and SOUZA, GC., 2003. Etnofarmacologia como ferramenta na busca de substâncias ativas. In SIMÕES, CMO., SCHENKEL, EP., GOSMANN, G., MELLO, JCP., MENTZ, LA. and PETROVICK, PR. (Orgs.). Farmacognosia: da planta ao medicamento. 5. ed. Porto Alegre: Editora da UFSC, Editora da UFRGS. p. 107-122.

FIUZA, TS, SILVA, PC., PAULA, JR., TRESVENZOL, LMF. and SABOIA-MORAIS, SMT., 2009. Bioactivity of crude ethanol extract and fractions of Eugenia uniflora (Myrtaceae) in the hepatopancreas of Oreochromis niloticus L. Biological Research, vol. 42, p. 401-414. http://dx.doi.org/10.4067/S071697602009000400002

GURGEL, APAD., SILVA, JG., GRANGEIRO, ARS., OLIVEIRA, DC., LIMA, CMP., SILVA, ACP., OLIVEIRA, RAG. and SOUZA, IA., 2009. In vivo study of the antiinflammatory and antitumor activities of leaves from Plectranthus amboinicus (Lour.) Spreng (Lamiaceae). Journal of Ethnopharmacology, vol. 125, p. 361-363. PMid:19607901. http://dx.doi.org/10.1016/j.jep.2009.07.006

HOLETZ, FB., PESSINI, GL., SANCHES, NR., CORTEZ, DAG., NAKAMURA, CV. and DIAS-FILHO, BP., 2002. Screening of some plants used in the brazilian folk medicine for the treatment of infectious diseases. Memórias do Instituto Oswaldo Cruz, vol. 97, no. 7, p. 1027-1031. http://dx.doi.org/10.1590/S007402762002000700017

LADEIRA, AM., ZAIDAN, LBP. and FIGUEIREDO-RIBEIRO, RCL., 1987. Ageratum conyzoides L. (Compositae): germinação, floração e ocorrência de derivados fenólicos em diferentes estádios de desenvolvimento. Hoehnea, vol. 15, p. 53-62.

LIEBERMAN, M., 1999. A brine shrimp bioassay for measuring toxicity and remediation of chemicals. Journal of Chemical Education, vol. 76, no. 12, p. 1689-1690. http://dx.doi.org/10.1021/ ed076p1689

LONGUEFOSSE, J. and NOSSIN, E., 1996. Medical ethnobotany survey in Martinique. Journal of Ethnopharmacology, vol. 53, no. 3, p. 117-142. http://dx.doi.org/10.1016/0378-8741(96)01425-0

LÓPEZ, CAA., 2006. Considerações gerais sobre plantas medicinais. Ambiente: Gestão e Desenvolvimento, vol. 1, no. 1, p. 19-27.

LORENZI, HE. and MATOS, FJA., 2002. Plantas medicinais no Brasil: Nativas e exóticas. Nova Odessa: Instituto Plantarum.

LUKHOBA, CW., SIMMONDS, MSJ. and PATON, AJ., 2006. Plectranthus: A review of ethnobotanical uses. Journal of Ethnopharmacology, vol. 103, p. 1-24. PMid:16289602. http:// dx.doi.org/10.1016/j.jep.2005.09.011

MACBAE, WD., HUDSON, JB. and TOWERS, GHN., 1988. Studies on the pharmacological activity of amazonian euphorbiaceae. Journal of Ethnopharmacology, vol. 22, no. 2, p. 143-172. http:// dx.doi.org/10.1016/0378-8741(88)90124-9

MAYORGA, P., PÉREZ, KR., CRUZ, SM. and CÁCERES, A., 2010. Comparison of bioassays using the anostracan crustaceans Artemia salina and Thamnocephalus platyurus for plant extract toxicity screening. Revista Brasileira de Farmacognosia, vol. 20, no. 6, p. 897-903. http://dx.doi.org/10.1590/S0102-695X2010005000029 
MOMESSO, LS., MOURA, RMX. and CONSTANTINO, DHJ., 2009. Atividade antitumoral do Ageratum conyzoides L. (Asteraceae). Revista Brasileira de Farmacognosia, vol. 19, no. 3, p. 660-663. http://dx.doi.org/10.1590/S0102-695X2009000500002

McLAUGHLIN, JL. and ROGERS, LL., 1988. The use of biological assays to evaluate botanicals. Drug Information Journal, vol. 32, p. 513-524.

MEYER, BN., FERRIGNI, NR., PUTNAM, JE., JACOBSEN, LB., NICHOLS, DE. and McLAUGHLIN, JL., 1982. Brine shrimp: A convenient general bioassay for active plant constituents. Planta Medica, vol. 45, p. 31-34. PMid:17396775. http://dx.doi. org/10.1055/s-2007-971236

NAKATANI, N. and NAGASHIMA, M., 1992. Pungent alkamides from Spilanthes acmella L. varoleracea Clarke. Bioscience, Biotechnology, and Biochemistry, vol. 56, no. 5, p. 759-762. http://dx.doi.org/10.1271/bbb.56.759

NUNES, LCC., GALINDO, AB., DEUS, ASO., ARCANJO, DDR., RANDAU, KP., XAVIER, HS., CITÓ, AMGL. and ROLIM-NETO, PJ., 2009. Variabilidade sazonal dos constituintes da própolis vermelha e bioatividade em Artemia salina. Revista Brasileira de Farmacognosia, vol. 19, no. 2B, p. 524-529.

ONG, HM., MOHAMAD, AS., MAKHTAR, N., KHALID, MH., KHALID, S., PERIMAL, EK., MASTUKI, SN., ZAKARIA, ZA., LAJIS, N., ISRAF, DA. and SULAIMAN, MR., 2010. Antinociceptive activity of methanolic extract of Acmella uliginosa (Sw.) Cass. Journal of Ethnopharmacology, vol. 133, no. 1, p. 227-233. PMid:20920570.
RAMSEWAK, RS., ERICKSON, AJ. and NAIR, MG., 1999. Bioactive $\mathrm{N}$-isobutylamides from the flower buds of Spilanthes acmella. Phytochemistry, vol. 51, no. 6, p. 729-732. http://dx.doi. org/10.1016/S0031-9422(99)00101-6

RAVISHANKAR, T., VEDAVALLI, L., NAMBI, AA. and SELVAM, V., 1994. Role of tribal people in the conservation and utilisations of plant genetic resources. Madras: MSSRF.

SAHPAZ, S., BORIES, CH., LOISEAU, PM., CORTÈS, D., HOCQUEMILLER, R., LAURENS, A. and CAVÉ, A., 1994. Cytotoxic and antiparasitic activity from Annona Senegalensis Seeds. Planta Medica, vol. 60, p. 538-540. PMid:7809207. http:// dx.doi.org/10.1055/s-2006-959566

SIQUEIRA, JM., BOMM, MD., PEREIRA, NFG., GARCEZ, WS. and BOAVENTURA, MAD., 1998. Estudo fitoquímico de Unonopsis lindmanii - Annonaceae, biomonitorado pelo ensaio de toxicidade sobre a Artemia salina Leach. Química Nova, vol. 21, no. 5, p. 557-559. http://dx.doi.org/10.1590/S010040421998000500004

TADESSE, D., EGUALE, T., GIDAY, M. and MUSSA, A., 2009. Ovicidal and larvicidal activity of crude extracts of Maesa lanceolata and Plectranthus punctatus against Haemonchus contortus. Journal of Ethnopharmacology, vol. 122, p. 240-244. PMid:19330920. http://dx.doi.org/10.1016/j.jep.2009.01.014

ZANI, CL., CHAVES, PPG., QUEIROZ, R., OLIVEIRA, AB., CARDOSO, JE., ANJOS, AMG. and GRANDI, TSM., 1995. Brine shrimp lethality assay as a prescreening system for anti-Trypanossoma Cruzi activity. Phytomedicine, vol. 2, p. 47. http://dx.doi.org/10.1016/S0944-7113(11)80048-6 
